\title{
Molecular differentiation of commercial varieties and feral populations of oilseed rape (Brassica napus L.)
}

\author{
Kathrin Pascher ${ }^{*}$, Susanne Macalka ${ }^{2}$, Domenico Rau ${ }^{3}$, Günter Gollmann ${ }^{4}$, Helmut Reiner ${ }^{5}$, Josef Glössl ${ }^{2}$, \\ Georg Grabherr'
}

\begin{abstract}
Background: For assessing the risk of escape of transgenes from cultivation, the persistence of feral populations of crop plants is an important aspect. Feral populations of oilseed rape, Brassica napus, are well known, but only scarce information is available on their population dynamics, particularly in Central Europe. To investigate genetic diversity, origin and persistence of feral oilseed rape in Austria, we compared variation at nine polymorphic microsatellite loci in eight feral populations with 19 commercial varieties.

Results: Overall, commercial varieties and feral populations showed a similar pattern of genetic variation and a similar level of observed heterozygosity. The two groups, however, shared less than $50 \%$ of the alleles and no multilocus genotype. A significant among-group (commercial varieties versus feral populations) component of genetic variation was observed (AMOVA: $F_{C T}=0.132$ ). Pairwise comparisons between varieties and feral populations showed moderate to very high genetic differentiation $\left(F_{\mathrm{ST}}=0.209-0.900\right)$. The software STRUCTURE also demonstrated a clear separation between commercial varieties and feral samples: out of 17 identified genetic clusters, only one comprised plants from both a commercial variety and feral sites.

Conclusions: The results suggest that feral oilseed rape is able to maintain persistent populations. The feral populations may have derived from older cultivars that were not included in our analyses or perhaps have already hybridised with related crops or wild relatives. Feral populations therefore have to be considered in ecological risk assessment and future coexistence measures as a potential hybridisation partner of transgenic oilseed rape.
\end{abstract}

\section{Background}

In the debate about the impact of transgenic plants on the environment, the containment of transgenes is a central issue [1]. Escape of transgenes could induce the evolution of new weeds or endanger the integrity of genetic resources in wild populations [2,3]. In gene transfer from crops to wild relatives, naturalized and feral populations of the crop plants themselves can form stepping stones for introgressive hybridization.

Oilseed rape, Brassica napus L., is an allotetraploid crop originating from hybridization between Brassica oleracea L. and Brassica rapa L. So far, there is no evidence that $B$. napus does exist as a wild plant but it

\footnotetext{
* Correspondence: kathrin.pascher@univie.ac.at

'University of Vienna, Department of Conservation Biology, Vegetation Ecology and Landscape Ecology, Rennweg 14, A-1030 Vienna, Austria
}

frequently appears as a feral crop outside cultivation. It shows many traits typical for wild plants, such as secondary seed dormancy, adaptation of its seed germination to the annual cycle and the easy dehiscence of its fruits. Although oilseed rape is autogamous to a high degree, cross fertilization is common (12 to 55\%) [4,5]. Carried by both vectors, wind and insects, Brassica pollen is able to pollinate flowers at distances of more than one kilometer [6,7]. A major concern for ecological risk assessment of transgenic oilseed rape is its potential for hybridization with related species $[8,9]$. Many species closely related to oilseed rape (e.g. B. rapa, Diplotaxis spp., Hirschfeldia incana, Rhaphanus raphanistrum, Sinapis arvensis) are found in agrotopes (field edges and meadows, loess slopes, shelterbelts, etc.) as well as ruderal habitats (road verges, railway embankments, slag heaps, etc.) [10]. Likewise, feral oilseed rape is a species 
of pioneer habitats, such as waste sites, cultivated grounds, rubble tips, arable fields, riverbanks, roadsides and tracks [11].

The persistence of feral populations therefore is an important aspect in ecological risk assessment of transgenic oilseed rape. Theoretical studies identified survival in the seed bank as the life history trait with the largest impact on population growth rate and persistence $[12,13]$. Origin and population dynamics of feral populations of B. napus have been studied in Western Europe. Pessel et al. [14] showed that feral oilseed rape persisted on road verges for at least eight years. In southern England most B. napus populations were transient and supplied mainly by seed input from trucks in transit [15], whereas in central France the origin of at least 35\% of feral populations from the seed bank was estimated by Pivard et al. [11]. In northwest Germany, some feral populations may persist via self-recruitment, as inferred from four years of field survey and assessment of genetic variation [16]. The situation in Central Europe is little known, and population genetics of feral oilseed rape populations have rarely been studied.

To investigate genetic diversity, origin and persistence of feral oilseed rape in Austria, we compared feral populations sampled in various seminatural habitats with 19 commercial varieties which had been widely released in Austria. To assess molecular variation, short sequence repeats (SSR) proved to be best suitable in an initial screening of several molecular marker systems (RAPD, AFLP, SINE, ISSR and SSR) [10]. In the statistical analysis of these data, we complement traditional population genetic methods with the assignment test implemented in the software STRUCTURE [17] in order to obtain information on population structure and gene flow.

\section{Results}

The observed number of alleles $\left(n_{a}\right)$ and the observed heterozygosity $\left(H_{O}\right)$ were not significantly different among the groups of commercial varieties and feral populations (Table 1, Wilcoxon: $P>0.05$ ). The same was true for the effective number of alleles $\left(n_{e}\right)$ and Nei's expected heterozygosity $\left(H_{E}\right)$ although the values obtained for the feral group were higher than those for the commercial varieties. When all feral individuals were considered in the analysis, a significant difference (Wilcoxon: $P<0.05)$ was found for the normalized Shannon's Index $\left(I_{\text {nor }}\right)$ for which the feral group was $47 \%$ genetically more diverse than the group of commercial varieties (Table 1). Considering the within-sample variability, only one of the analysed samples (the commercial variety 'Idol') was genetically uniform $\left(I_{\text {nor }}=0.00\right.$, Table 2). In all samples heterozygous individuals were identified although considerable among-sample variation in the observed heterozygosity $\left(H_{O}\right)$ was found. When all the 224 individuals were analysed, 85 SSR alleles were detected, of which only 38 (45\%) were shared between the commercial varieties and the feral groups (Table 3 ). A high number of private alleles (i.e. exclusive of each group) was observed both for the commercial varieties $(19,22 \%)$ and the feral group $(28,33 \%)$. When the 13 single feral oilseed rape plants from different sites were excluded from the analysis, the proportion of shared alleles between the two groups slightly increased (35 out of 74 alleles, $47 \%$ ) and the number of private alleles of the feral group was reduced from 28 to $17(20 \%)$.

The difference in allelic frequencies between the group of commercial varieties and the group of the eight feral populations of $B$. napus was moderate and significant $\left(F_{\mathrm{CT}}=0.132, P=0.0009\right.$; Table 4a). When the two groups were considered separately, genetic divergence was strong, both among samples of commercial varieties $\left(F_{\mathrm{ST}}=0.606, P<0.0001\right)$ and among the feral populations (Table $4 \mathrm{~b}, F_{\mathrm{ST}}=0.466, P<0.0001$ ). Pairwise $F_{\mathrm{ST}}$ values for all combinations of feral populations versus samples from commercial varieties ranged from 0.209 to 0.900 (Table 5, with $P<0.05$ in all cases and $P<0.001$ in $93 \%$ of the cases), i.e. from moderate to nearly complete genetic differentiation, with an average of $0.584 \pm$ 0.143 (strong genetic differentiation). The inbreeding level was lower within varieties $\left(F_{\mathrm{IS}}=-0.020, P>0.05\right)$ than within feral populations $\left(F_{\mathrm{IS}}=0.361, P<0.0001\right)$.

In the cluster analysis of samples, $B$. rapa samples were well separated from $B$. napus (Figure 1). Cutting the cluster at a genetic distance of 1.00 , two clusters of $B$. napus samples and a singleton could be obtained. The singleton was represented by the variety 'Mohican'. The two clusters correlated partially with variety types and seed-companies. In the lower cluster eight out of nine varieties were open pollinated (OP) (except 'Cannon') and six out of nine were from Saatbau Linz. This cluster also included two varieties ('Gazelle', 'Impala') which served as pollen donors but were never released in Austria. In the uppermost cluster all the restored hybrid cultivar ( $\mathrm{rHy}$ ) varieties were present. Seven of the eight feral populations were included in the upper cluster, with some (\#84, \#71, \#80 and \#118) closer to the commercial varieties than others (\#70, \#128 and \#74).

Genotypes of $B$. rapa were also well separated from those of $B$. napus in an UPGMA-tree based on individual genotypes (Figures 2 and 3). Whereas individuals within both commercial varieties and feral populations often shared the same multilocus genotype, no multilocus genotype was shared between commercial varieties and feral populations.

Applying the method of Evanno et al. [18] to identify the most likely number of 'true populations', we found $K=18$ genetic groups. With one exception - group 4 was both represented by individuals from a commercial 
Table 1 Locus by locus descriptive genetic statistics, for both commercial varieties and feral groups.

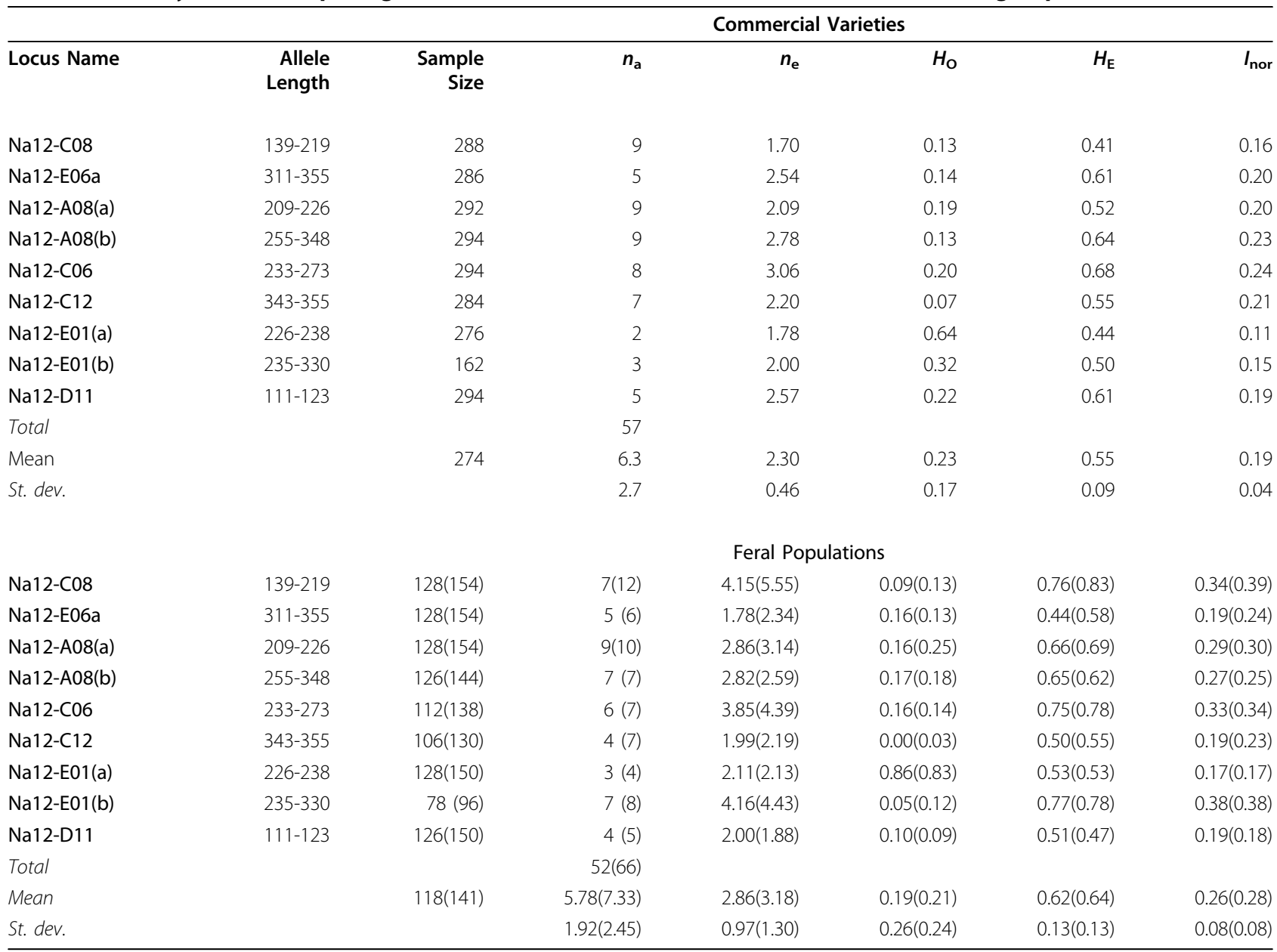

$n_{a}=$ observed number of alleles; $n_{e}=$ effective number of alleles [51]; $H_{O}=$ observed heterozygosity; $H_{E}=$ Nei's [40] unbiased expected heterozygosity; $I_{\text {nor }}=$ normalized Shannon's Index [41,42]. For feral populations all statistics are given both, considering only the eight populations (64 individuals) or, in brackets, also including the 13 single individuals (77 individuals). For characteristics of the nine B. napus SSR-loci used see Lowe et al. [38]. The primer sequences are listed in BrassicaDB http://ukcrop.net.

variety ('Karola') and feral populations (\#71, \#84) - the assignment procedure of STRUCTURE showed a clear separation between commercial varieties and feral samples (Figure 4). Ten genetic groups were found exclusively among the commercial varieties, each of them comprising one to four varieties. Several variety samples were genetically homogenous, whereas others included some 'deviant' genotypes. Seven genetic groups were resolved among the feral samples, most of them occurring at several sites. Whereas some feral populations appear to be genetically homogeneous (\#128, \#154) others show a mixture of highly diverse genotypes (notably \#70 and \#74). Remarkably, the single feral plants, sampled over a wide area, tend to cluster together (7 out of 13 individuals were attributed to the same group with a proportion of membership > 70\%) and, despite some individuals were strongly admixed (\#156-1,\#130-1, \#170-2, \#169, \#149, \#166), it is also noticeable that all share some similar genetic characteristics. Both commercial and feral samples include a few individuals which were assigned to two different genetic groups with nearly equal probability, suggestive of a hybrid origin (e.g. individual \#130-1, feral group 17 and group 18 otherwise represented by the variety 'Mohican').

\section{Discussion}

The feral populations of B. napus appeared to be genetically differentiated from the commercial varieties included in our study. Overall, both groups showed a similar population genetic make-up with a similar level of genetic diversity both within and between samples. Commercial oilseed rape varieties and feral populations, however, shared less than $50 \%$ of the SSR alleles and not a single multilocus genotype. A moderate level of genetic differentiation, $13 \%$ of the total molecular 
Table 2 Descriptive genetic statistics for commercial varieties samples and feral populations.

\begin{tabular}{|c|c|c|c|c|c|c|c|c|}
\hline Sample name & $\begin{array}{r}\text { Sample } \\
\text { Size } \\
\end{array}$ & $n_{\mathrm{a}}$ & $n_{\mathrm{e}}$ & $\begin{array}{r}\text { Polymorphic } \\
\text { Loci (\%) } \\
\end{array}$ & $H_{\mathrm{O}}$ & $H_{\mathrm{E}}$ & $\begin{array}{l}\text { Number of } \\
\text { Genotypes }\end{array}$ & $I_{\text {nor }}$ \\
\hline \multicolumn{9}{|l|}{ Commercial Varieties } \\
\hline 'Artus' & $8(15.78)$ & 1.56 & 1.27 & 55.6 & 0.26 & 0.16 & 4 & 0.52 \\
\hline 'Cannon' & $8(14.89)$ & 2.00 & 1.49 & 66.7 & 0.31 & 0.27 & 7 & 0.92 \\
\hline 'Columbus' & $8(16.00)$ & 1.33 & 1.16 & 22.2 & 0.13 & 0.10 & 3 & 0.35 \\
\hline 'Express' & $8(13.78)$ & 1.63 & 1.26 & 50.0 & 0.17 & 0.17 & 3 & 0.35 \\
\hline 'Falcon' & $8(15.56)$ & 1.67 & 1.36 & 44.4 & 0.16 & 0.20 & 7 & 0.92 \\
\hline 'Fornax' & $8(14.22)$ & 2.38 & 1.67 & 87.5 & 0.25 & 0.32 & 8 & 1.00 \\
\hline 'Gazelle' & $8(14.22)$ & 1.25 & 1.16 & 25.0 & 0.13 & 0.10 & 2 & 0.18 \\
\hline 'Honk' & $8(15.56)$ & 1.78 & 1.40 & 22.2 & 0.08 & 0.15 & 8 & 1.00 \\
\hline 'Idol' & $8(16.00)$ & 1.11 & 1.11 & 11.1 & 0.11 & 0.06 & 1 & 0.00 \\
\hline 'Impala' & $8(14.00)$ & 1.63 & 1.53 & 62.5 & 0.24 & 0.30 & 8 & 1.00 \\
\hline 'Karola' & $8(16.00)$ & 2.11 & 1.54 & 88.9 & 0.21 & 0.31 & 7 & 0.92 \\
\hline 'Lady' & 8 (15.78) & 1.78 & 1.25 & 66.7 & 0.13 & 0.18 & 4 & 0.52 \\
\hline 'Lirajet' & 8 (15.56) & 1.67 & 1.51 & 44.4 & 0.29 & 0.24 & 5 & 0.67 \\
\hline 'Mohican' & $8(14.44)$ & 1.44 & 1.25 & 44.4 & 0.14 & 0.15 & 3 & 0.47 \\
\hline 'Panther' & $5(7.78)$ & 2.33 & 1.82 & 100.0 & 0.39 & 0.55 & 5 & 1.00 \\
\hline 'Phantom' & $6(9.11)$ & 2.00 & 1.60 & 66.6 & 0.19 & 0.36 & 5 & 0.87 \\
\hline 'Pronto' & $8(16.00)$ & 1.56 & 1.52 & 55.6 & 0.43 & 0.28 & 4 & 0.64 \\
\hline 'Synergy' & 8 (15.78) & 2.67 & 1.65 & 100.0 & 0.42 & 0.39 & 7 & 0.35 \\
\hline 'Zeus' & $8(14.00)$ & 1.38 & 1.30 & 37.5 & 0.26 & 0.17 & 4 & 0.58 \\
\hline Average & 7.74 & 1.75 & 1.41 & 55.33 & 0.23 & 0.23 & 5 & 0.65 \\
\hline Total & 147 & & & & & & 90 & 0.85 \\
\hline \multicolumn{9}{|l|}{ Feral Populations } \\
\hline \# 70 & $8(14.67)$ & 2.67 & 1.83 & 100.0 & 0.17 & 0.47 & 6 & 0.80 \\
\hline \# 71 & $8(15.33)$ & 2.22 & 1.86 & 88.9 & 0.22 & 0.45 & 6 & 0.83 \\
\hline \# 74 & $8(12.44)$ & 2.22 & 1.61 & 62.5 & 0.17 & 0.31 & 6 & 0.80 \\
\hline \# 80 & $8(14.67)$ & 2.22 & 1.79 & 77.8 & 0.20 & 0.38 & 8 & 1.00 \\
\hline \# 84 & $8(15.56)$ & 2.22 & 1.44 & 77.8 & 0.16 & 0.28 & 7 & 0.92 \\
\hline \#118 & $8(16.00)$ & 2.44 & 1.64 & 88.9 & 0.19 & 0.35 & 8 & 1.00 \\
\hline$\# 128$ & $8(16.00)$ & 1.22 & 1.13 & 22.2 & 0.13 & 0.07 & 2 & 0.18 \\
\hline$\# 154$ & $8(13.11)$ & 1.63 & 1.37 & 50.0 & 0.34 & 0.21 & 4 & 0.58 \\
\hline Average & 8 & 2.11 & 1.58 & 71.01 & 0.20 & 0.32 & 5.88 & 0.76 \\
\hline Total & 64 & & & & & & 47 & 0.84 \\
\hline \multicolumn{9}{|l|}{13 Feral Genotypes } \\
\hline (each of different origin) & 13 & 4.89 & 2.74 & 100.0 & 0.31 & 0.58 & 13 & 1.00 \\
\hline Total & 77 & & & & & & 60 & 0.91 \\
\hline
\end{tabular}

$n_{a}=$ observed number of alleles; $n_{e}=$ effective number of alleles [51]; $H_{O}=$ observed heterozygosity; $H_{E}=$ Nei's [40] unbiased expected heterozygosity; $I_{\text {nor }}=$ normalized Shannon's Index $[41,42]$. Sample size is given both as number of individuals analysed and (between bracket) as average number of data per locus. The incomplete genotyping is due to technical reasons.

variation, was observed between the two groups of plants. None of the eight feral populations could be related to any investigated variety, although some showed similarities to certain cultivars: most plants from samples \#71 und \#84 cluster with the variety 'Karola', which appears genetically heterogeneous itself.

Microsatellite (SSR) markers are suitable to identify varieties of oilseed rape [19]. We cannot exclude that small sample sizes and seed contamination (as inferred by the observed heterogeneity of several variety samples) may have limited our ability to detect genetic contributions of some varieties to the feral populations. In seed production, varietal purity of oilseed rape can only be achieved with great effort due to pollination from uncontrolled sources [20] [K. Fischer, personal communication]. In Austria, the purity of oilseed rape varieties is not controlled on a genetic basis but only by checking morphological characteristics [21]. 
Table 3 Comparison between commercial varieties and feral populations (64 individuals) of B. napus for shared and private SSR alleles.

\begin{tabular}{|c|c|c|c|c|c|}
\hline & \multirow[b]{2}{*}{ Sample Size } & \multirow[b]{2}{*}{ Number of Alleles } & \multirow[b]{2}{*}{ Number of Shared Alleles } & \multicolumn{2}{|c|}{ Number of Private Alleles } \\
\hline & & & & Commercial & Feral \\
\hline $\mathrm{Na} 12-\mathrm{C} 08$ & $416(442)$ & $13(17)$ & $3(4)$ & $6(5)$ & $4(8)$ \\
\hline $\mathrm{Na12-E06a}$ & $414(440)$ & $7(7)$ & $3(4)$ & $2(1)$ & $2(2)$ \\
\hline Na12-A08(a) & $420(446)$ & $11(12)$ & $7(7)$ & $2(2)$ & $2(3)$ \\
\hline $\mathrm{Na12-A08(b)}$ & $420(438)$ & $10(10)$ & $6(6)$ & $3(3)$ & $1(1)$ \\
\hline $\mathrm{Na} 12-\mathrm{C} 06$ & $406(432)$ & $9(10)$ & $5(5)$ & $3(3)$ & $1(2)$ \\
\hline $\mathrm{Na} 12-\mathrm{C} 12$ & $390(414)$ & $8(10)$ & $3(4)$ & $4(3)$ & $1(3)$ \\
\hline Na12-E01(a) & $404(426)$ & $3(4)$ & $2(2)$ & $0(0)$ & $1(2)$ \\
\hline $\mathrm{Na12-E01(b)}$ & $240(258)$ & 7 (8) & $3(3)$ & $0(0)$ & $4(5)$ \\
\hline $\mathrm{Na12-D11}$ & $420(444)$ & $6(7)$ & $3(3)$ & $2(2)$ & $1(2)$ \\
\hline Total & & $74(85)$ & $35(38)$ & 22(19) & $17(28)$ \\
\hline Mean & $392(416)$ & $8.22(9.44)$ & 3.89 & $2.44(2.11)$ & $1.89(3.11)$ \\
\hline St. dev. & & 2.95(3.68) & 1.69 & $1.88(1.62)$ & $1.27(2.15)$ \\
\hline
\end{tabular}

For data in parentheses, the 13 sampling sites of single feral individuals are included (altogether 77 individuals).

Table 4 Analysis of molecular variance (AMOVA) for 19 commercial varieties and eight feral populations of $B$. napus.

\begin{tabular}{|c|c|c|c|c|}
\hline Source of Variation & d.f. & Sum of Squares & $\begin{array}{r}\text { Variance } \\
\text { Components } \\
\end{array}$ & Percentage of Variation \\
\hline \multicolumn{5}{|l|}{ a } \\
\hline Among groups & 1 & 86.469 & $0.360\left(V_{a}\right)$ & 13.19 \\
\hline Among samples within groups & 25 & 549.007 & $1.331\left(V_{b}\right)$ & 48.81 \\
\hline Among individuals within samples & 184 & 215.258 & $0.134\left(V_{c}\right)$ & 4.90 \\
\hline Within individuals & 211 & 190.500 & $0.903\left(V_{d}\right)$ & 33.10 \\
\hline Total & 421 & 1041.235 & $2.727\left(V_{T}\right)$ & \\
\hline Fixation Indices & $F_{I S}=0.129^{*}$ & $F_{S C}=0.562^{* *}$ & $F_{C T}=0.132^{* *}$ & $F_{\mathrm{TT}}=0.669^{* *}$ \\
\hline \multicolumn{5}{|l|}{$b$} \\
\hline \multicolumn{5}{|l|}{ Commercial Varieties } \\
\hline Among varieties & 18 & 405.929 & $1.400\left(V_{a}^{\prime}\right)$ & 60.70 \\
\hline Among individuals within varieties & 128 & 113.758 & $-0.018\left(V_{b}^{\prime}\right)$ & -0.79 \\
\hline Within individuals & 147 & 136.000 & $0.925\left(V_{c}^{\prime}\right)$ & 40.09 \\
\hline Total & 293 & 655.687 & $2.308\left(V_{T}^{\prime}\right)$ & \\
\hline Fixation Indices & $F_{I S}=0.020^{n s}$ & $F_{\mathrm{ST}}=0.606^{* *}$ & $F_{\mathrm{IT}}=0.599^{* *}$ & \\
\hline \multicolumn{5}{|l|}{ Feral Populations } \\
\hline Among populations & 7 & 143.078 & $1.164\left(V_{\mathrm{a}}^{\prime}\right)$ & 46.64 \\
\hline Among individuals within populations & 56 & 101.500 & $0.480\left(V_{b}^{\prime}\right)$ & 19.25 \\
\hline Within individuals & 64 & 54.500 & $0.852\left(V_{c}^{\prime}\right)$ & 34.11 \\
\hline Total & 127 & 299.078 & $2.496\left(V_{T}^{\prime}\right)$ & \\
\hline Fixation Indices & $F_{I S}=0.361^{* *}$ & $F_{S T}=0.466^{* *}$ & $F_{I T}=0.659^{* *}$ & \\
\hline
\end{tabular}

For each group, total molecular variance is partitioned into three components: among groups (commercial varieties versus feral populations), among populations within groups and within populations.

${ }^{*} P<0.001,{ }^{* *} P<0.0001$ (based on 100000 permutations). 
Table 5 Values of $F_{\mathrm{ST}}$ for all possible combinations between feral populations and commercial varieties of $B$. napus.

\begin{tabular}{|c|c|c|c|c|c|c|c|c|c|c|c|}
\hline Feral Populations & & & & & Comm & rcial Varieti & & & & & \\
\hline & 'Artus' & 'Cannon' & 'Columbus' & 'Express' & 'Falcon' & 'Fornax' & 'Gazelle' & 'Honk' & 'Idol' & 'Impala' & \\
\hline \# 70 & 0.615 & 0.470 & 0.644 & 0.595 & 0.540 & 0.485 & 0.648 & 0.597 & 0.580 & 0.477 & \\
\hline \# 71 & 0.563 & 0.469 & 0.580 & 0.574 & 0.440 & 0.465 & 0.656 & 0.595 & 0.538 & 0.486 & \\
\hline \# 74 & 0.678 & 0.527 & 0.720 & 0.694 & 0.607 & 0.578 & 0.725 & 0.692 & 0.660 & 0.605 & \\
\hline$\# 80$ & 0.636 & 0.570 & 0.681 & 0.671 & 0.558 & 0.557 & 0.680 & 0.668 & 0.575 & 0.577 & \\
\hline \# 84 & 0.696 & 0.585 & 0.745 & 0.726 & 0.610 & 0.605 & 0.779 & 0.701 & 0.699 & 0.610 & \\
\hline$\# 118$ & $0.673^{* *}$ & 0.600 & 0.690 & 0.576 & 0.625 & 0.534 & 0.649 & 0.687 & 0.558 & 0.594 & \\
\hline$\# 128$ & 0.847 & 0.681 & 0.881 & 0.826 & 0.835 & 0.732 & 0.870 & 0.824 & 0.900 & 0.698 & \\
\hline$\# 154$ & 0.747 & 0.615 & 0.695 & 0.661 & 0.738 & 0.515 & 0.689 & 0.659 & 0.794 & 0.541 & \\
\hline Mean & 0.682 & 0.565 & 0.704 & 0.666 & 0.619 & 0.559 & 0.712 & 0.678 & 0.663 & 0.574 & \\
\hline s.d. & 0.087 & 0.073 & 0.087 & 0.086 & 0.121 & 0.084 & 0.078 & 0.072 & 0.129 & 0.072 & \\
\hline & 'Karola' & 'Lady' & 'Lirajet' & 'Mohican' & 'Panther' & 'Phantom' & 'Pronto' & 'Synergy' & 'Zeus' & Mean & s.d. \\
\hline \# 70 & 0.396 & 0.608 & 0.479 & 0.575 & $0.239^{*}$ & $0.310^{* *}$ & 0.401 & 0.353 & 0.483 & 0.500 & 0.118 \\
\hline \# 71 & 0.332 & 0.537 & 0.464 & 0.599 & $0.209^{*}$ & $0.270^{* *}$ & 0.373 & 0.359 & 0.429 & 0.470 & 0.120 \\
\hline \# 74 & 0.407 & 0.667 & 0.615 & 0.678 & $0.355^{* *}$ & 0.449 & 0.532 & 0.448 & 0.599 & 0.591 & 0.111 \\
\hline$\# 80$ & 0.403 & 0.660 & 0.577 & 0.659 & 0.218 & 0.256 & 0.428 & 0.350 & 0.408 & 0.533 & 0.146 \\
\hline$\# 84$ & 0.338 & 0.683 & 0.603 & 0.734 & 0.347 & 0.439 & 0.541 & 0.500 & 0.580 & 0.606 & 0.128 \\
\hline$\# 118$ & 0.547 & 0.680 & 0.608 & 0.663 & $0.315^{* *}$ & $0.283^{* *}$ & 0.512 & 0.432 & $0.496^{* *}$ & 0.564 & 0.117 \\
\hline$\# 128$ & 0.694 & 0.832 & 0.722 & 0.837 & $0.651^{* *}$ & 0.715 & 0.661 & 0.610 & 0.794 & 0.769 & 0.089 \\
\hline$\# 154$ & 0.610 & 0.681 & 0.639 & 0.768 & 0.503 & 0.563 & 0.577 & 0.480 & 0.669 & 0.639 & 0.092 \\
\hline Mean & 0.466 & 0.668 & 0.588 & 0.689 & 0.355 & 0.411 & 0.503 & 0.442 & 0.557 & 0.584 & 0.143 \\
\hline s.d. & 0.134 & 0.083 & 0.084 & 0.087 & 0.153 & 0.164 & 0.097 & 0.090 & 0.130 & 0.143 & \\
\hline
\end{tabular}

All $F_{\mathrm{ST}}$ values were significant for $P<0.001$ except where specified: ${ }^{*} P<0.05$, $\left.{ }^{*} P<0.01\right)$. With the exception of 'Panther' (5) and 'Phantom' (6) sample size was eight for each commercial variety.

Founding events and genetic drift could have a significant role in shaping the population genetic structure of feral populations. The rather large genetic differences among feral populations and the comparatively high level of inbreeding of the feral individuals support this hypothesis. Some feral populations appeared to be genetically fairly homogeneous, suggesting their origin from a single founding event. Other sites show highly heterogeneous genetic composition, suggesting that they received seed input from several sources, and probably over several years. The genetically most diverse stand of feral oilseed rape was found at a railway embankment (\#70), other mixed populations were sampled along roads (\#74, \#118) and a river bank (\#71), all habitats likely to receive repeated influx of seeds and to experience repeated disturbance.

Several genetic clusters of feral plants occurred at sites separated by large distances, the single plants sampled from mostly small feral populations were assigned to the same cluster. These genetic similarities among feral plants could be caused by common ancestry from varieties that are no longer cultivated, by selection favouring or eliminating certain alleles of loci linked to the markers, or perhaps also by hybridization with related species. In any case, the data suggest that these feral populations already existed for several years. Thus, our findings corroborate the results obtained by Pessel et al. [14], using chemical compounds and isozyme analyses, of at least eight years persistence of feral $B$. napus in France. Pessel et al. [14] mainly observed homogeneous sites with all plants showing the same genotype, but $23 \%$ of their sites contained a mixture of plants with different genotypes and/or hybrid genotypes. In our study, all feral sites contained more than one genotype. This difference can be explained by the high resolving power of SSR markers in comparison with the chemical compounds and isozyme analyses or by more frequent outcrossing events in our study region. Recently, Elling et al. [16] observed high diversity of multilocus genotypes (using a subset of the SSR loci scored in our study) in feral B. napus populations in northwest Germany; $58 \%$ percent of the feral plants could be assigned to one of seven reference varieties. The detection of hybrids between varieties and of many private alleles in feral plants indicates persistence of feral populations, an outcome that mirrors our results.

Several lines of evidence suggest that containment of transgenic oilseed rape will be hard to achieve. Colonization success of feral populations of $B$. napus critically depends on human or natural disturbances $[10,15,22]$. 


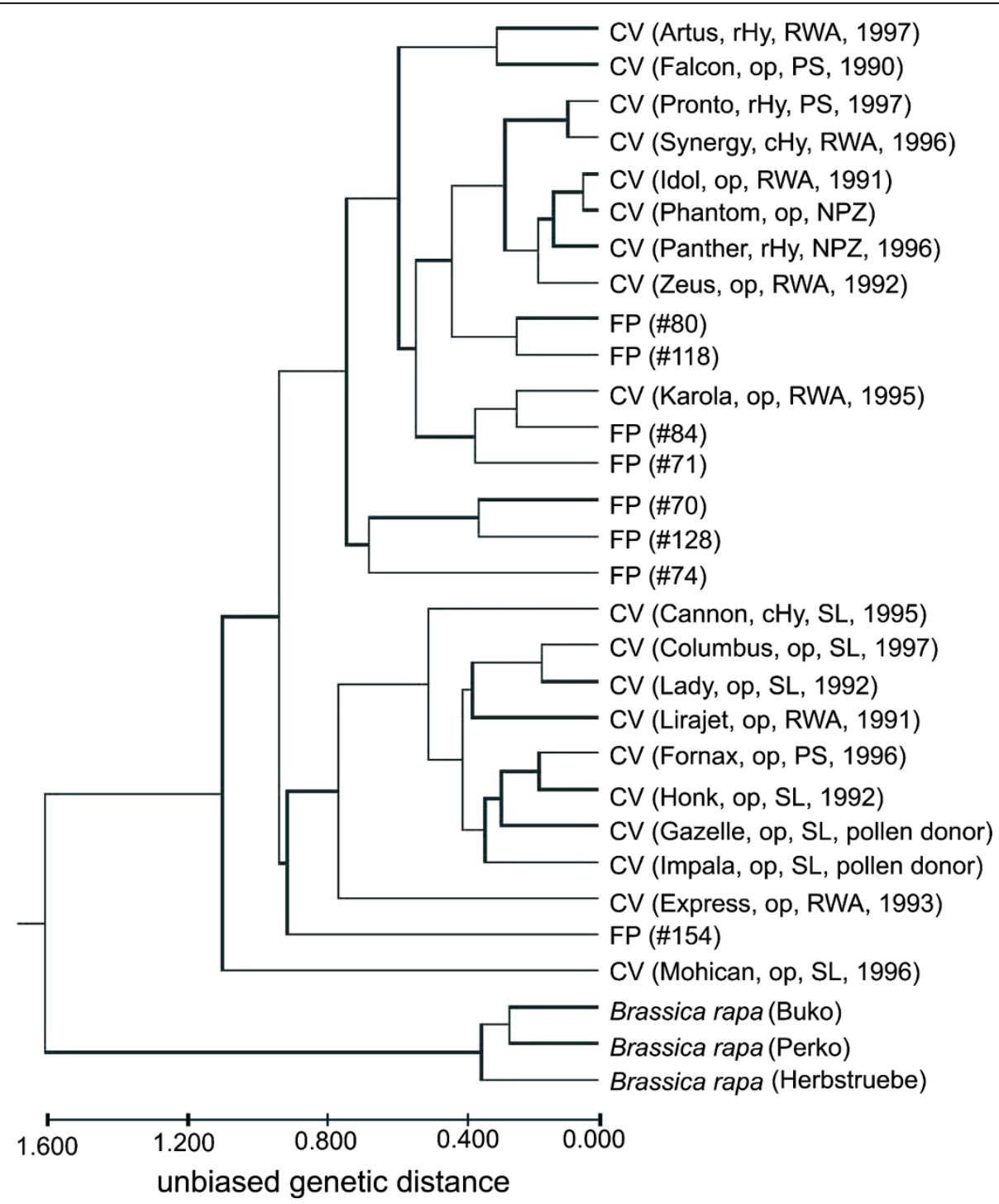

Figure 1 Relationship among samples based on Nei's [40] unbiased genetic distance and UPGMA clustering [43]. FP = feral populations, $\mathrm{CV}=$ commercial varieties; variety type: $\mathrm{OP}=$ open pollinated, $\mathrm{CHy}=$ composite hybrid, $\mathrm{rHy}=$ restored hybrid. Seed company: NPZ = Norddeutsche Pflanzenzucht, PS = Probstdorfer Saatzucht, RWA = Raiffeisen Ware Austria, SL = Saatbau Linz. The year of approval for each variety is also indicated.

Volunteers of oilseed rape in arable fields are common, and have been found by Austrian plant breeders for at least twelve years after the last oilseed rape crop [H. Schrems, personal communication]. Volunteers of genetically modified herbicide resistant oilseed rape have already been observed up to ten years after field trials $[23,24]$. Long range seed dispersal could be caused by road traffic $[25,26]$. In Canada, where herbicide resistant varieties have been cultivated at large scale, volunteers as well as feral populations with multiple herbicide resistance occur, whose origin is attributed to pollen flow among cultivars with different resistance traits [5,27]. Introgression of a herbicide resistance transgene into a weedy population of $B$ rapa has already occurred in Canada [28]. Hybridization of B. napus has also been observed with its other parent species, B. oleracea [29], and with several other related species $[8,30]$.

Small scale agriculture typical for Austria is characterized by a variety of landscape elements separating small fields [31]. In these agrotopes, numerous feral oilseed rape plants can be found as well as many related species of Brassicaceae, both weedy crops and native species [22]. The abundance and flowering phase of these species differ among regions even in a small country such as Austria [10]. Therefore, detailed taxonomic and ecological knowledge of the regional flora is vital for 


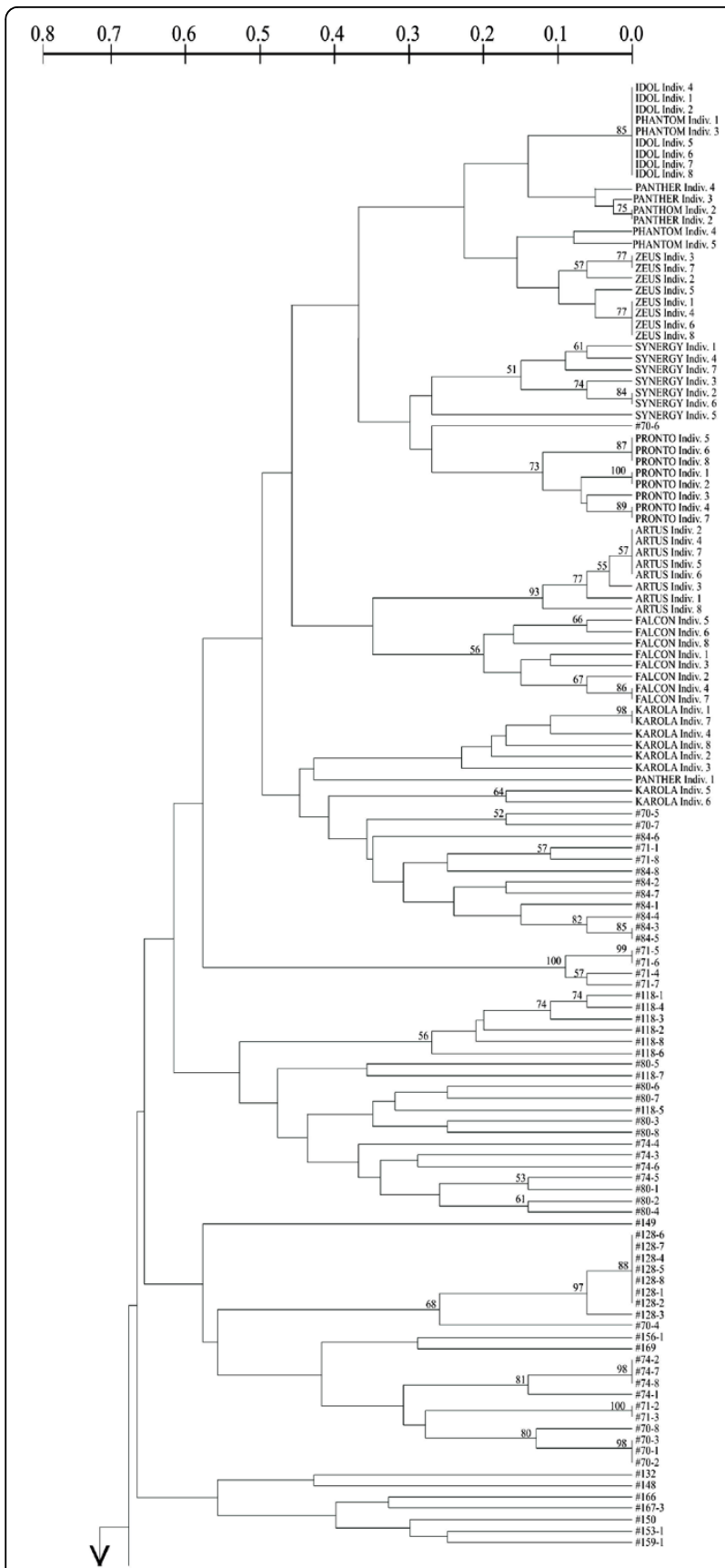

Figure 2 Relationship among single individuals of $B$. napus based on Nei and Li genetic distances and UPGMA. For

comparison individuals from three commercial varieties of $B$. rapa were also included. Nei and Li [48] genetic distances and UPGMA method implemented in Treecon ver. 1.b software [49] were used. For this analysis each SSR allele was coded as a single locus with two states, 0 (absent) or 1 (present) [50]. The consistency of each node was assayed by bootstrapping (i.e. resampling with replacement) with 1000 replicates using Treecon ver. 1.3b software [49]. Only bootstrap values (\%) over 50 are reported in the figure.

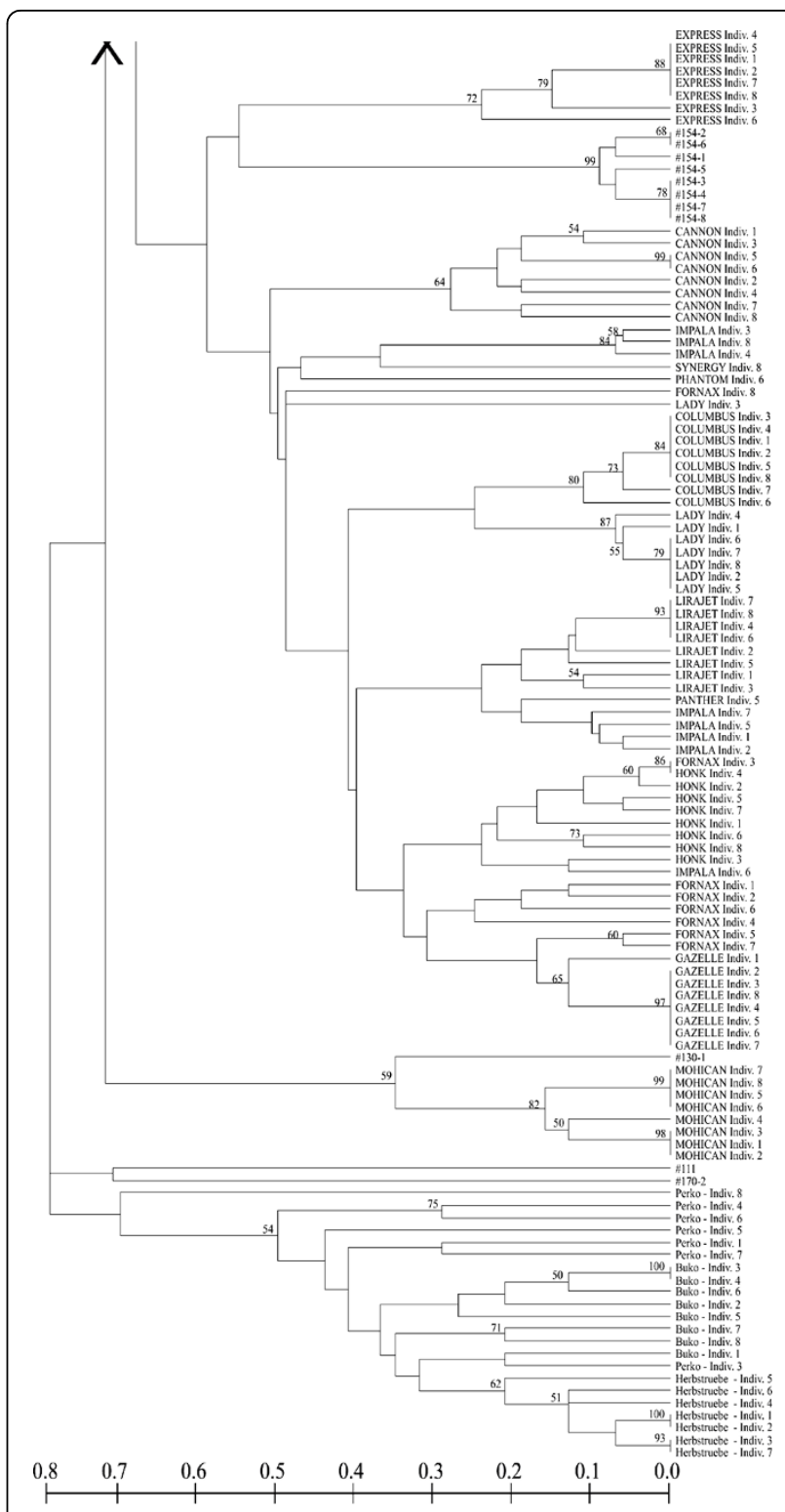

Figure 3 Relationship among single individuals of $B$. napus based on Nei and Li genetic distances and UPGMA. Figure 2 continued, for detailed description see Figure 2.

risk assessment of genetically modified plants [32]. Even when hybridization between crops and their wild relatives is rare, introgression of transgenes can have pervasive effects on the wild populations, especially if they confer a fitness advantage to the plants carrying them, as can be expected from traits contributing to pest resistance or stress tolerance $[9,33]$.

At present, coexistence of farming with genetically modified (GM) and non-GM crops is vehemently 


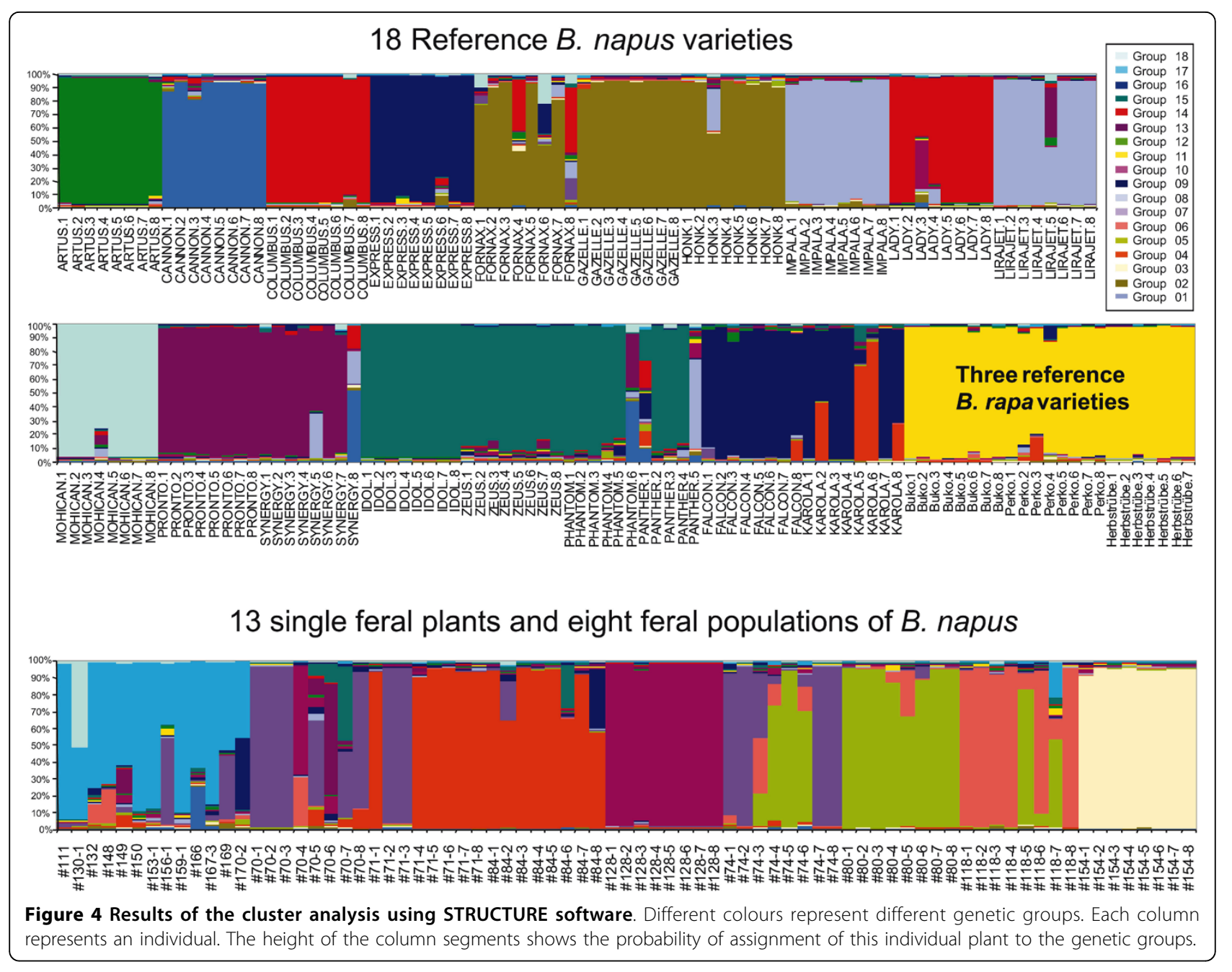

debated $[22,34,35]$. In this context, feral populations of crops play an important role as sources and corridors for gene transfer [14]. In view of the persistence of feral populations, as suggested by our results, and all the available evidence on seed survival, gene flow and introgressive hybridization of oilseed rape, coexistence of GM and non-GM oilseed rape can hardly be achieved without compromising the interests of GM-free agriculture. These problems for coexistence are particularly important in Austria with its small scale landscape structure and a high proportion of organic farmers opposed to using transgenic crops.

\section{Conclusions}

The genetic divergence between feral samples and commercial varieties indicates that feral oilseed rape is able to maintain persistent populations. These feral populations have to be considered in ecological risk assessment and coexistence measures as a relevant hybridisation partner of transgenic oilseed rape.

\section{Methods}

\section{Sampling of plant material and DNA extraction}

Following a survey of feral oilseed rape populations in Austria [10], eight feral B. napus populations consisting of more than ten plants were selected for genetical investigation, chosen to maximize habitat diversity (Table 6; Figure 5). We sampled eight individuals per population. In addition, thirteen single oilseed rape plants - each from a different sampling site - were also included for a total of 77 feral individuals to be genetically analysed. Fresh and cold treated leaves $\left(4^{\circ} \mathrm{C}\right)$ were used for DNA-analyses. Fieldwork was carried out during spring, summer and autumn in 1998 and 1999. Seeds from 19 oilseed rape commercial varieties, as well as three varieties of $B$. rapa, which were widely grown in Austria from 1990 to 1999 were obtained from Austrian and German breeders and seed trading companies (Table 7). Seeds of commercial varieties were germinated and the apex of the secondary leaves of the young plants was used for DNA extraction with 
Table 6 Characterization of the investigated plant material (feral oilseed rape; OSR) and its sampling sites.

\begin{tabular}{|c|c|c|c|c|c|}
\hline $\begin{array}{l}\text { Analysed } \\
\text { Plants }\end{array}$ & $\begin{array}{l}\text { Sampling } \\
\text { Number }\end{array}$ & $\begin{array}{l}\text { Number of } \\
\text { Individuals } \\
\text { Analysed }\end{array}$ & $\begin{array}{l}\text { Estimated } \\
\text { Population } \\
\text { Size }\end{array}$ & Sampling Location & $\begin{array}{l}\text { Characterization of Sampling } \\
\text { Sites }\end{array}$ \\
\hline B. napus & $\# 70$ & $1-8$ & 15 & Lower Austria, Lassee & railway embankment \\
\hline Feral & \# 71 & $1-8$ & 25 & Burgenland, Podersdorf & along a wet river bank \\
\hline \multirow[t]{6}{*}{ Populations } & \# 74 & $1-8$ & 30 & Lower Austria, St. Pölten & verge of a motorway \\
\hline & $\# 80$ & $1-8$ & 20 & City of Vienna & $\begin{array}{l}\text { excavated soil in front of a new } \\
\text { building }\end{array}$ \\
\hline & \# 84 & $1-8$ & 25 & Vienna, Danube Island & excavated soil \\
\hline & $\# 118$ & $1-8$ & 30 & Lower Austria, Pfaffstätten & traffic island \\
\hline & $\# 128$ & $1-8$ & several 100s & $\begin{array}{l}\text { Burgenland, Rohr im } \\
\text { Burgenland }\end{array}$ & approximately five year old fallow \\
\hline & $\# 154$ & $1-8$ & 30 & Lower Austria, Hexenbühel & loess embankment \\
\hline B. napus & $\# 111$ & 1 & small & Upper Austria, Enns & $\begin{array}{l}\text { road verge in front of a petrol } \\
\text { station }\end{array}$ \\
\hline \multirow[t]{12}{*}{$\begin{array}{l}\text { Single } \\
\text { Feral Plants }\end{array}$} & $\# 130$ & 1 & 30 & $\begin{array}{l}\text { Burgenland, Rohr im } \\
\text { Burgenland }\end{array}$ & maize field (volunteer) \\
\hline & $\# 132$ & 1 & single plant & $\begin{array}{l}\text { Burgenland, Rohr im } \\
\text { Burgenland }\end{array}$ & $\begin{array}{l}\text { field margin, } 10 \text { m next to an OSR } \\
\text { field }\end{array}$ \\
\hline & $\# 148$ & 1 & big & Styria, near Großlobming & bean field (volunteer) \\
\hline & $\# 149$ & 1 & single plant & Styria, Großlobming & road verge \\
\hline & $\# 150$ & 1 & very big & Styria, Großlobming & ripe OSR field, second blossoming \\
\hline & $\# 153$ & 1 & $<50$ & Lower Austria, Hexenbühel & fallow \\
\hline & $\# 156$ & 1 & 5 & Upper Austria & road embankment \\
\hline & $\# 159$ & 1 & 15 & Vienna, Danube Island & sidewalk verge \\
\hline & $\# 166$ & 1 & several & $\begin{array}{l}\text { Upper Austria, near } \\
\text { Schärding }\end{array}$ & strawberry field \\
\hline & $\# 167$ & 1 & 5 & $\begin{array}{l}\text { Upper Austria, near } \\
\text { Stuben }\end{array}$ & $\begin{array}{l}\text { road verge adjacent to } \\
\text { a maize field }\end{array}$ \\
\hline & \#169 & 1 & several & $\begin{array}{l}\text { Upper Austria, near } \\
\text { Eggerding }\end{array}$ & field (volunteer) \\
\hline & $\# 170$ & 1 & 5 & $\begin{array}{l}\text { Upper Austria, near } \\
\text { Forchtenau }\end{array}$ & road verge \\
\hline
\end{tabular}

Cetyltrimethyl-Ammonium-Bromid (CTAB) method [36]. The extraction protocol followed Doyle and Doyle [37].

\section{SSR-analyses (Simple Sequence Repeats)}

Thirty-nine SSR primers were tested [38]. Nine loci which were polymorphic and with stable amplification were used in the present study (Table 3). Scoring of genotypes was conducted via PCR with fluorescent primers [39] followed by DNA-fragment separation with an automatic DNA-sequencer on the basis of capillary electrophoresis (ABI 373 and ABI 310 DNA sequencer from Applied Biosystems).

\section{Statistical analyses}

To evaluate the level of genetic diversity of both commercial varieties and feral $B$. napus populations the following statistics were calculated: the percentage of polymorphic loci, the number of alleles $\left(n_{a}\right.$, per locus and average), the effective number of alleles $\left(n_{e}\right.$, per locus and average), the expected $\left(H_{E},[40]\right)$ and the observed $\left(H_{O}\right)$ heterozygosity, the number of unique genotypes and the normalized Shannon's Index ( $I_{\text {nor }}$, either with allele frequencies at a locus or the frequencies of multilocus genotypes [41,42]). The softwares PopGene ver. 1.31 [43] and TFPGA ver 1.3 [44] were used. The significance of the differences between the groups of commercial varieties and that of feral populations were tested using the Wilcoxon non parametric test implemented in JMP ver 3.1.5 software [45].

In order to evaluate population structure, the total genetic variation $\left(V_{T}\right)$ was partitioned performing the Analysis of Molecular Variance (AMOVA, [46]) with hierarchical levels. The analysis was repeated considering the two groups (commercial variety and feral populations) separately. The pairwise $F_{\mathrm{ST}}$ matrix among samples was also obtained and the significance of each $F_{\mathrm{ST}}$ was calculated with 3.000 permutations. All calculations were made by using Arlequin ver. 2.0 software [47]. 


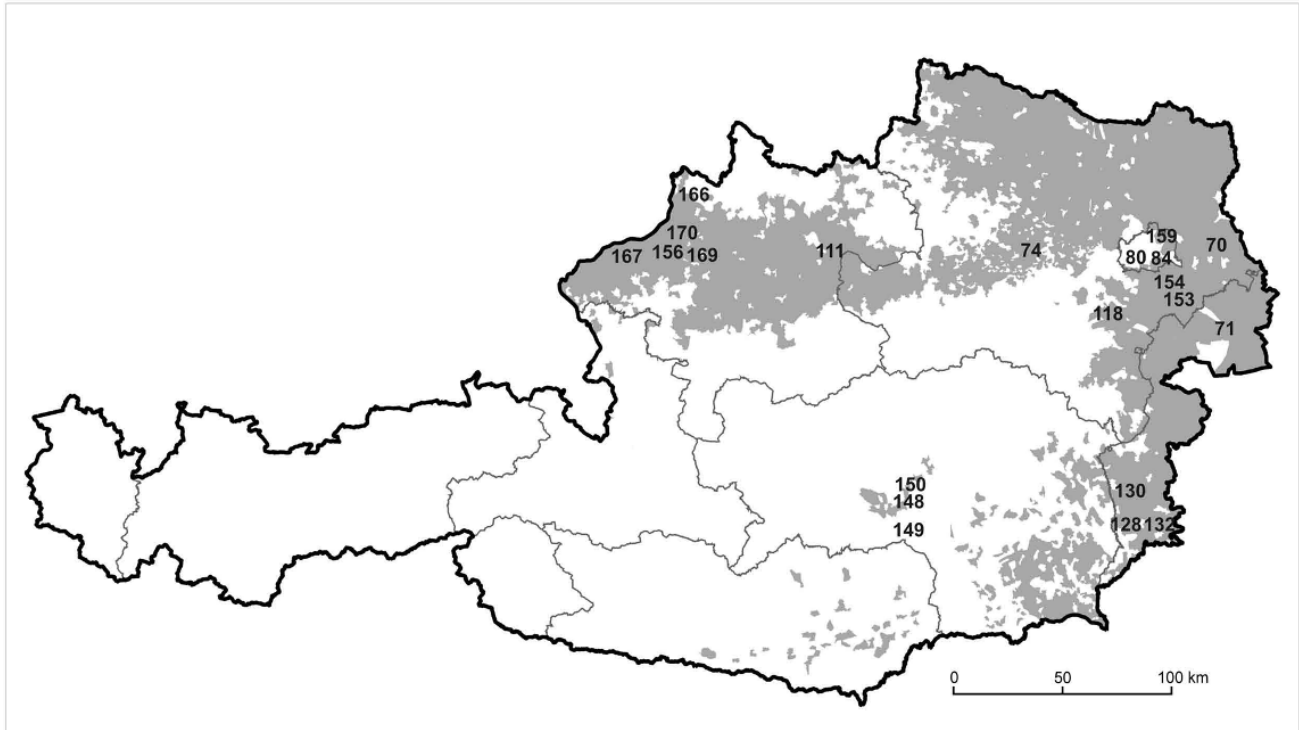

Figure 5 Locations of the sampling sites on the map of Austria. The locations of the sampling sites of the eight analysed feral populations and of the thirteen single plants (sampling numbers) are shown. The grey shading indicates the cultivation areas of oilseed rape, lines show the borders of the provinces of Austria.

Table 7 Oilseed rape and Brassica rapa commercial varieties widely grown in Austria from 1990 to 1999.

\begin{tabular}{|c|c|c|c|}
\hline $\begin{array}{l}\text { Name of } \\
\text { Commercial Variety }\end{array}$ & Pollination System & $\begin{array}{l}\text { Breeders and Seed } \\
\text { Trading Companies }\end{array}$ & Date of Approval \\
\hline \multicolumn{4}{|l|}{ Brassica napus } \\
\hline 'Artus' & rHy & RWA & 05.08.1997 \\
\hline 'Cannon' & VA 75 hybrid, cHy & $S L$ & 04.08.1995 \\
\hline 'Columbus' & o. p. & $S L$ & 05.08.1997 \\
\hline 'Express' & o. p. & RWA & 16.12 .1993 \\
\hline 'Falcon' & o. p. & PS & 18.12 .1990 \\
\hline 'Fornax' & o. p. & PS & 06.08.1996 \\
\hline 'Gazelle' & o. p. & $\mathrm{SL}$ & pollen donor \\
\hline 'Honk' & o. p. & $S L$ & 17.12.1992 \\
\hline 'Idol' & o. p. & RWA & 17.12.1991 \\
\hline 'Impala' & o. p. & $S L$ & pollen donor \\
\hline 'Karola' & o. p. & RWA & 19.12.1995 \\
\hline 'Lady' & o. p. & $\mathrm{SL}$ & 17.12.1992 \\
\hline 'Lirajet' & o. p. & RWA & 17.12.1991 \\
\hline 'Mohican' & o. p. & $S L$ & 06.08.1996 \\
\hline 'Panther' & $\mathrm{rHy}$ & NPZ & 1996 \\
\hline 'Phantom' & o. p. & NPZ & - \\
\hline 'Pronto' & $\mathrm{rHy}$ & PS & 05.08.1997 \\
\hline 'Synergy' & $\mathrm{cHy}$ & RWA & 19.12.1996 \\
\hline 'Zeus' & o. p. & RWA & 1992 \\
\hline \multicolumn{4}{|l|}{ Brassica rapa } \\
\hline 'Buko' & o. p. & PS & 17.12.1981 \\
\hline 'Perko PVH' & o. p. & ÖRWZ & 15.12.1967 \\
\hline 'Herbstrübe' & o. p. & undefined variety & undefined variety \\
\hline
\end{tabular}

(source: Österreichische Sortenliste 1998)

rHy: restored hybrid, cHy: composite hybrid, o. p.: open pollinated;

RWA: Raiffeisen Ware Austria, SL: Saatbau Linz, PS: Probstdorfer Saatzucht, NPZ: Norddeutsche Pflanzenzucht, ÖRWZ: Österreichische Raiffeisen Warenzentrale. 
Relationships among samples were studied by obtaining a dendrogram applying UPGMA method based on a matrix of Nei [40] pairwise genetic distances using PopGene ver. 1.31 [43]. Twenty-seven samples of B. napus (19 of commercial varieties and eight of feral populations) and three samples of $B$. rapa were included in this analysis. Relationships among the individuals were described with a dendrogram by UPGMA method based on Nei and Li [48] pairwise genetic distances matrix.

Population structure was also inferred using the Bayesian method implemented in STRUCTURE Ver. 2.1 software [17], that infers the number of clusters (populations), $K$, present in a sample by comparing the posterior probability for different numbers of putative populations specified by the user and assigns individuals giving a percentage of membership (q) to these clusters. Twenty independent runs for each $K$ (from 1 to 21 ) were performed using 100,000 MCMC repetitions and 100,000 burn-in periods, using no prior information and assuming correlated allele frequencies and admixture. The number of clusters $(K)$ was estimated computing the ad hoc statistic $\Delta K$, based on the rate of change in the log probability of the data between successive $K$ values [18].

\section{Acknowledgements}

We acknowledge funding by the Austrian Federal Ministry for Health and Women. We thank Keith Edwards (IACR, Long Ashton Research Station, UK), Martin Trick and Carolyn Moule (John Innes Center, Norwich, UK) for providing the SSR primer sequences and the possibility to use the laboratory of M. Trick. We are grateful to Karl Fischer (Saatbau Linz) and Heinrich Schrems (Saatzucht Donau) for agronomic information and to Roberto Papa and Stefan Dullinger for stimulating discussion. Martin Prinz and Christa Renetzeder helped with formatting the paper.

\section{Author details}

'University of Vienna, Department of Conservation Biology, Vegetation Ecology and Landscape Ecology, Rennweg 14, A-1030 Vienna, Austria. ${ }^{2}$ University of Natural Resources and Applied Life Sciences, Department of Applied Genetics and Cell Biology, Muthgasse 18, A-1190 Vienna, Austria. ${ }^{3}$ Università degli Studi di Sassari, Dipartimento di Scienze Agronomiche e Genetica Vegetale Agraria, Via E De Nicola n 1, I-07100 Sassari, Italy. ${ }^{4}$ University of Vienna, Department of Evolutionary Biology and Department of Limnology, Althanstraße 14, A-1090 Vienna, Austria. ${ }^{5}$ Grünentorgasse 19/ 12, A-1090 Vienna, Austria.

\section{Authors' contributions}

KP, JG and GGr designed and organized this research, KP and HR obtained the samples, SM carried out the molecular assays, DR performed the statistical analyses and contributed to the writing of the paper. DR, GGo and KP provided interpretation of results, KP and GGo wrote the paper. All authors read and approved the paper.

Received: 15 June 2009 Accepted: 1 March 2010

Published: 1 March 2010

\section{References}

1. Chapman MA, Burke JM: Letting the gene out of the bottle: the population genetics of genetically modified crops. New Phytologist 2006, 170:429-443

2. Ellstrand NC, Prentice HC, Hancock JF: Gene flow and introgression from domesticated plants into their wild relatives. Ann Rev Ecol Syst 1999, 30:539-563.
3. Pilson D, Prendeville HR: Ecological effects of transgenic crops and the escape of transgenes into wild populations. Ann Rev Ecol Syst 2004, 35:149-174.

4. Becker HC, Damgaard C, Karlsson B: Environmental variation for outcrossing rate in rapeseed (Brassica napus). Theor Appl Genet 1992, 84:303-306.

5. Beckie HJ, Warwick SI, Nair H, Seguin-Swartz GS: Gene flow in commercial fields of herbicide-resistant canola (Brassica napus). Ecological Applications 2003, 13:1276-1294.

6. Devaux C, Klein EK, Lavigne C, Sausse C, Messean A: Environmental and landscape effects on cross-pollination rates observed at long distance among French oilseed rape Brassica napus commercial fields. J Appl Ecol 2008, 45:803-812.

7. Hayter KE, Cresswell JE: The influence of pollinator abundance on the dynamics and efficiency of pollination in agricultural Brassica napus: implications for landscape-scale gene dispersal. J Appl Ecol 2006, 43:1196-1202.

8. Chèvre A-M, Ammitzbø\| $H$, Breckling $B$, Dietz-Pfeilstetter $A$, Eber $F$, Fargue A, Gomez-Campo C, Jenczewski E, Jørgensen R, Lavigne C, Meier MS, den Nijs HCM, Pascher K, Seguin-Swartz G, Sweet J, Stewart CN $\mathrm{Jr}$, Warwick S: A review on interspecific gene flow from oilseed rape to wild relatives. Introgression from Genetically Modified Plants into Wild Relatives UK: CABI publishingden Nijs HCM, Bartsch D, Sweet J 2004, 235-251.

9. Hails RS, Morley K: Genes invading new populations: a risk assessment perspective. Trends Ecol Evol 2005, 20:245-252.

10. Pascher K, Macalka-Kampfer S, Reiner H: Vegetationsökologische und genetische Grundlagen für die Risikobeurteilung von Freisetzungen von transgenem Raps und Vorschläge für ein Monitoring. Wien: Bundesministerium für Soziale Sicherheit und Generationen 2000, 7.

11. Pivard S, Adamczyk K, Lecomte J, Lavigne C, Bouvier A, Deville A, Gouyon PH, Huet S: Where do the feral oilseed rape populations come from? A large-scale study of their possible origin in a farmland area. $J$ Appl Ecol 2008, 45:476-485.

12. Claessen D, Gilligan CA, Lutman PJW, Bosch van den F: Which traits promote persistence of feral GM crops? Part 1: implications of environmental stochasticity. Oikos 2005, 110:20-29.

13. Claessen D, Gilligan CA, Bosch van den F: Which traits promote persistence of feral GM crops? Part 2: implications of metapopulation structure. Oikos 2005, 110:30-42.

14. Pessel FD, Lecomte J, Emeriau V, Krouti M, Messean A, Gouyon PH: Persistence of oilseed rape (Brassica napus L.) outside of cultivated fields. Theor Appl Genet 2001, 102:841-846.

15. Crawley MJ, Brown SL: Spatially structured population dynamics in feral oilseed rape. Proc R Soc B 2004, 271:1909-1916.

16. Elling B, Neuffer B, Bleeker W: Sources of genetic diversity in feral oilseed rape (Brassica napus) populations. Basic Appl Ecol 2009, 10:544-553.

17. Pritchard JK, Stephens M, Donnelly P: Inference of population structure using multilocus genotype data. Genetics 2000, 155:945-959.

18. Evanno G, Regnaut S, Goudet J: Detecting the number of clusters of individuals using the software STRUCTURE: a simulation study. Mol Ecol 2005, 14:2611-2620.

19. Devaux C, Lavigne C, Falentin-Guyomarc'h H, Vautrin S, Lecomte J, Klein EK: High diversity of oilseed rape pollen clouds over an agro-ecosystem indicates long-distance dispersal. Mol Ecol 2005, 14:2269-2280.

20. Friesen LF, Nelson AG, Van Acker RC: Evidence of contamination of pedigreed canola (Brassica napus) seedlots in western Canada with genetically engineered herbicide resistance traits. Agron J 2003, 95:1342-1347.

21. AGES: Die Produktion von Saatgut in abgegrenzten Erzeugungsprozessen zur Vermeidung einer Verunreinigung mit gentechnisch veränderten Organismen im Kontext mit der Koexistenz von konventioneller Landwirtschaft mit oder ohne GVO und ökologischer Landwirtschaft. Wien: Österreichische Agentur für Gesundheit und Ernährungssicherheit GmbH 2004.

22. Pascher K, Dolezel M: Koexistenz von gentechnisch veränderten, konventionellen und biologisch angebauten Kulturpflanzen in der österreichischen Landwirtschaft - Handlungsempfehlungen aus ökologischer Sicht. Forschungsbericht der Sektion IV Wien: Bundesministeriums für Gesundheit und Frauen 2005, 2:1-317. 
23. D'Hertefeldt $T$, Jorgensen RB, Pettersson LB: Long-term persistence of GM oilseed rape in the seedbank. Biology Letters 2008, 4:314-317.

24. Lutman PJW, Berry K, Payne RW, Simpson E, Sweet JB, Champion GT, May MJ, Wightman P, Walker K, Lainsbury M: Persistence of seeds from crops of conventional and herbicide tolerant oilseed rape (Brassica napus). Proc R Soc B 2005, 272:1909-1915.

25. Garnier A, Pivard S, Lecomte J: Measuring and modelling anthropogenic secondary seed dispersal along roadverges for feral oilseed rape. Basic Appl Ecol 2008, 9:533-541.

26. Lippe von der M, Kowarik I: Crop seed spillage along roads: a factor of uncertainty in the containment of GMO. Ecography 2007, 30:483-490.

27. Knispel AL, McLachlan SM, Van Acker RC, Friesen LF: Gene flow and multiple herbicide resistance in escaped canola populations. Weed Science 2008, 56:72-80.

28. Warwick SI, Legere A, Simard MJ, James T: Do escaped transgenes persist in nature? The case of an herbicide resistance transgene in a weedy Brassica rapa population. Mol Ecol 2008, 17:1387-1395.

29. Ford CS, Allainguillaume J, Grilli-Chantler P, Cuccato G, Allender CJ, Wilkinson MJ: Spontaneous gene flow from rapeseed (Brassica napus) to wild Brassica oleracea. Proc R Soc B 2006, 273:3111-3115.

30. Warwick SI, Simard MJ, Legere A, Beckie HJ, Braun L, Zhu B, Mason P, Seguin-Swartz G, Stewart CN: Hybridization between transgenic Brassica napus L. and its wild relatives: Brassica rapa L., Raphanus raphanistrum L., Sinapis arvensis L. and Erucastrum gallicum (Willd.) OE Schulz. Theor Appl Genet 2003, 107:528-539.

31. Wrbka T, Schindler S, Pollheimer M, Schmitzberger I, Peterseil J: Impact of the Austrian Agri-Environmental Scheme on diversity of landscapes, plants and birds. Community Ecol 2008, 9:217-227.

32. Pascher K, Gollmann G: Ecological risk assessment of transgenic plant releases: an Austrian perspective. Biodivers Conserv 1999, 8:1139-1158.

33. Vacher C, Weis AE, Hermann D, Kossler T, Young C, Hochberg ME: Impact of ecological factors on the initial invasion of Bt transgenes into wild populations of birdseed rape (Brassica rapa). Theor Appl Genet 2004, 109:806-814

34. Altieri MA: The Myth of Coexistence: Why transgenic crops are not compatible with agroecologically based systems of production. Bulletin of Science Technology Society 2005, 25:361-371.

35. Jank B, Rath J, Gaugitsch H: Co-existence of agricultural production systems. Trends Biotechnol 2006, 24:198-200.

36. Murray MG, Thompson WF: Rapid isolation of high molecular-weight plant DNA. Nucl Acids Res 1980, 8:4321-4325.

37. Doyle J, Doyle J: A rapid DNA isolation procedure for small quantities of fresh leaf tissue. Phytochemical Bulletin 1987, 19:11-15.

38. Lowe AJ, Moule C, Trick M, Edwards KJ: Efficient large-scale development of microsatellites for marker and mapping applications in Brassica crop species. Theor Appl Genet 2004, 108:1103-1112.

39. Szewc-McFadden AK, Kresovich S, Bliek SM, Mitchell SE, McFerson JR: Identification of polymorphic, conserved simple sequence repeats (SSRs) in cultivated Brassica species. Theor App/ Genet 1996, 93:534-538.

40. Nei M: Estimation of average heterozygosity and genetic distance from a small number of individuals. Genetics 1978, 89:583-590.

41. Kumar J, Nelson RJ, Zeigler RS: Population structure and dynamics of Magnaporthe grisea in the Indian Himalayas. Genetics 1999, 152:971-984.

42. Hutcheson K: A test for comparing diversities based on Shannon formula. J Theor Biol 1970, 29:151.

43. Yeh FC, Boyle T, Rongcai Y, Ye Z, Xian JM: Popgene version 1.31. Microsoft window-based Freeware for population Genetic Analysis. University of Alberta, Edmonton 1999.

44. Miller M: TFPGA. Tools for Population Genetic Analysis. Version 1.3. Northern Arizona University 1997.

45. SAS-Institute: JMP Software. SAS Institut Inc. copyright 1995

46. Excoffier L, Smouse PE, Quattro JM: Analysis of molecular variance inferred from metric distances among DNA haplotypes: Application to human mitochondrial DNA restriction data. Genetics 1992, 131:479-491.

47. Schneider S, Kueffer J, Roessli D, Excoffier L: ARLEQUIN Ver. 1.1: a Software for Population Genetic Data Analysis. Genetic and Biometry Laboratory, Univ of Geneva 1997.

48. Nei M, Li WH: Mathematical model for studying genetic variation in terms of restriction endonucleases. Proc Nat Acad Sci USA 1979, 76:5269-5273.
49. Peer Van de $Y$, Dewachter R: Treecoon for Windows: a software package for the construction and drawing of evolutionary trees for the Microsoft Windows environment. Computer Applications in the Biosciences 1994, 10:569-570.

50. Powell W, Morgante M, Doyle JJ, McNicol JW, Tingey SV, Rafalski AJ: Genepool variation in genus Glycine subgenus Soja revealed by polymorphic nuclear and chloroplast microsatellites. Genetics 1996, 144:792-803.

51. Kimura M, Crow JF: The measurement of effective population number. Evolution 1963, 17:279-288.

doi:10.1186/1471-2148-10-63

Cite this article as: Pascher et al:: Molecular differentiation of commercial varieties and feral populations of oilseed rape (Brassica napus L.). BMC Evolutionary Biology 2010 10:63.

\section{Submit your next manuscript to BioMed Central and take full advantage of:}

- Convenient online submission

- Thorough peer review

- No space constraints or color figure charges

- Immediate publication on acceptance

- Inclusion in PubMed, CAS, Scopus and Google Scholar

- Research which is freely available for redistribution

Submit your manuscript at www.biomedcentral.com/submit
C) Biomed Central 